\title{
IAMJ
}

INTERNATIONAL

AYURVEDIC

MEDICAL JOURNAL

\section{RANDOMIZED OPEN LABELLED CLINICAL TRIAL OF HERBAL COOKIES AND HERBAL SOUP ON DYSMENORRHOEA - A GUJCOST SPONSORED MINOR RESEARCH PROJECT}

\section{Jasmine Gujarathi ${ }^{1}$, Pravin M Ganorkar ${ }^{2}$, Dilip Jani ${ }^{3}$, K Rukmini ${ }^{4}$}

${ }^{1}$ Professor \& Head, Dept of Prasuti Tantra and Stri Roga. G. J Patel Institute of Ayurveda studies and Research, New Vallabh Vidyanagar, Anand, Gujarat, India

${ }^{2}$ Assistant Professor, Department of Food Processing Technology, A.D. Patel Institute of Technology, New Vallabh Vidya Nagar, Anand - 388121, Gujarat, India

${ }^{3}$ Professor, Dept of Dravyaguna, Govt Ayurveda College, Baroda

${ }^{4}$ Associate Professor, Dept of Rasashastra, G. J Patel Institute of Ayurveda studies and Research, New Vallabh Vidyanagar, Anand, Gujarat, India

Corresponding Author: jassyleo@gmail.com

\section{https://doi.org/10.46607/iamj05p5012020}

(Published online: November 2020)

Open Access

(C) International Ayurvedic Medical Journal, India 2020

Article Received: 10/10/2020 - Peer Reviewed: 20/10/2020 - Accepted for Publication: 22/10/2020

\section{Check for updates}

\begin{abstract}
Introduction: Dysmenorrhoea is one of the gynaecological pathogenesis commonly observed in the society in young and adolescent girls. It is associated with painful cramps during menstruation of uterine origin with association of nausea, vomiting, constipation or diarrhoea. Various methods are practiced relieving pain and such symptoms but the search for herbal nutritive formulations to cure this is in search.

Methodology: The present clinical study was randomized open labelled clinical trial amongst 150 unmarried girls suffering from painful menstruation between age group of 13 to 25 . Performa was prepared to analyse data and pain before and after treatment. The population samples were randomly divided into three group with $R a$ japravartini Vati as control group, another two groups were administered herbal soup and herbal cookies.
\end{abstract}


Results: Percentage relief in pain was $84.9 \%$ in cookies, $63.64 \%$ in soup group and $45.83 \%$ in Rajapravartni group. $51.35 \%$ girls showed complete relief in dysmenorrhoea in cookies group, $40.54 \%$ in soup group and $32.43 \%$ in Rajapravartini group.

Conclusion: Palatability and acceptability of herbal soup and cookies along with effectiveness in relieving painful menstruation was significant.

Keywords: Dysmenorrhoea, herbal cookies, herbal soup

\section{INTRODUCTION}

Dysmenorrhea is still an important public health problem which may have a negative impact on health, social environment, work and psychological status ${ }^{1}$. Some of the studies have determined that prevalence of dysmenorrhea decrease with increasing age thus indicating that primary dysmenorrhea peaks in late adolescent by 20 s and then the incidence falls with increasing age. ${ }^{2}$ Prevalence studies also have shown several other factors that are associated with dysmenorrhea like body mass index (BMI), smoking, early menarche, prolonged menstrual flow and psychological disturbances.

According to a survey conducted by investigators of this project of about 798 girls of rural and urban areas, $47.02 \%$ of girls had dysmenorrhoea and $85.65 \%$ of girls missed school / college every month during menstruation in which $40.71 \%$ girls remained absent for whole day. The girls were reluctant to take any medications for the fear of side effect of allopathic medicines or palatability of Ayurveda medicines. ${ }^{3}$

The condition of dysmenorrhoea in young girls is explained in Ayurveda under Udavartini Yonivyapad which is similar to spasmodic dysmenorrhoea. ${ }^{4}$ With an aim to provide herbal nutritive, palatable and restorative formulations with properties of balancing Vata Dosha causing pain and relieving other symptoms, herbal soup and cookies were designed and clinical study was done on 150 girls.

\section{Materials and Methods}

Duration of Study: July 2016 to July 2018 (2 years)

\section{Methodology for New preparations}

New dosage form was prepared as herbal soup and herbal cookies from twelve herbs named Sunthi, Jeeraka, Krishna Jeeraka, Pippali, Ajmoda, Dhanyaka, Hingu, Garjara Beeja, Moolaka Beeja, Shatava- ri, Yastimadhu and Kumari. Quotations were invited from vendors and were procured after analysis. All herbs were evaluated for quality testing at G J Patel Institute of Ayurvedic Studies and Research, A \& R Patel Institute of Biotechnology and Applied Studies (ARIBAS).

Pharmacognostical evaluation of all herbs done at pharmacognosy department of Indukaka Ipcowala College of Pharmacy (IICP).

Base material for soup and cookies were also procured similarly.

\section{Methodology of Pharmacognostic evaluation:}

Macroscopical studies of aerial parts of plant were done by naked eye and shape, color, taste and odor were determined and reported.

Pharmacognostical evaluation including histochemical study was carried out by taking free-hand sections according to Wallis and powder studies according to Evans. The section was stained with phloroglucinol and concentrated $\mathrm{HCl}$ solution and mounted in glycerine. Powder Sieve mesh 60 of the dried aerial parts was used for the observation of powder microscopical character. Photomicrographs were obtained by observing free-hand sections of drug under compound microscope.

Heavy metal analysis done at Sophisticated Instrumentation Centre for Applied Research and Testing (SICART)

Methodology of preparation of herbal soup and herbal cookies

All the herbs were powdered separately at Pharmacy of G J Patel institute of Ayurvedic studies and Research. The powders were prepared with the help of Pulvarizer and fine powder They were stored in airtight bags properly at room temperature. Batches of 
laboratory scale soup and cookies were prepared at Food technology department of ADIT college. Sensory evaluation was carried out by a panel of ten judges. Hedonic rating test was employed using 9-point hedonic scale (from like extremely -9 to dislike extremely -1). Sensory parameters such as color, taste, texture and overall acceptability were evaluated Nutritional evaluation was done for fat, protein and carbohydrate content. Scale up formulation of $110 \mathrm{~kg}$ cookies and $110 \mathrm{~kg}$ soup were prepared in Pharmacy of G J Patel Institute of Ayurveda studies and research.

\section{Clinical Study \\ Criteria for Inclusion}

1. Age group between 13 to 25 unmarried complaining of either painful and or irregular menstruation

2. Pain with scanty or average amount of menstruation

\section{Criteria for Exclusion}

1. Girls suffering from excessive menstruation

2. Girls below 13 years and above 25 years

3. Any chronic illness

4. Any uterine pathology like fibroid, adenomyosis, endometriosis
The girls were provided with detailed information sheet and informed consent was taken after making them understand about the study. A detailed performa was prepared for data collection and analysis of the study.

\section{Study Design}

The present clinical study was randomized open labeled clinical trial. The randomization method used was simple random technique through numbering.

Ethical approval: The proposal of clinical study was approved by institutional ethical committee. IEC3/GJPIASR/2015-16/1(15)

CTRI Registration: Clinical trial was registered prospectively. CTRI/2018/02/011980

Investigations: Before and after treatment Routine hematological investigations like complete blood count, differential blood count, haemoglobin, packed cell volume, serum calcium were done. Urine: Routine and microscopic examination

Ultrasonography (USG): USG for uterine and adnexal study was done only for cases suspected of any pathology.

\section{Posology:}

Table 1: The dose and duration of all groups

\begin{tabular}{|l|l|l|l|}
\hline & Group C (Trial group) & Group S (Trial group) & Group R (control group) \\
\hline Formulation & Herbal cookies & Herbal soup & Tablet Rajapravartini vati \\
\hline Dose & $\begin{array}{l}2 \text { cookie approx 23 gm twice a } \\
\text { day }(2.5 \mathrm{gms} \text { herbal mixture in } \\
\text { one serving) }\end{array}$ & $\begin{array}{l}30 \mathrm{gm} \text { twice a day } \\
(2.5 \mathrm{gms} \text { herbal mixture in one } \\
\text { serving) }\end{array}$ & $\begin{array}{l}\text { 2 tablets (approx 500 mg) twice a } \\
\text { day }\end{array}$ \\
\hline Route & Oral & Oral \\
\hline $\begin{array}{l}\text { Duration } \\
\begin{array}{l}\text { consecutive } \\
\text { cycles }\end{array}\end{array}$ & $\begin{array}{l}1^{\text {st }} \text { cycle }-15 \text { days before Menstruation } \\
2^{\text {nd }} \text { Cycle }-10 \text { days before menstruation } \\
3^{\text {rd }} \text { Cycle }-7 \text { days before menstruation }\end{array}$ & \\
\hline Time period & Morning before breakfast - Evening before dinner & \\
\hline
\end{tabular}

Criteria of Assessment: To assess the effect of therapy, subjective scoring pattern was used with signs and symptoms of painful menstruation.

Statistical Analysis: Statistical evaluation of subjective and objective parameters was done with Sigma Stat Software by applying paired $t$ test and unpaired $t$ test.

\section{Observation and Results:}

\section{Standardization of Raw materials}

Organoleptically all procured herbs were found to be as per API.

Pharmacognostical study of herbal mixture. 
Fig 1: Powder study characters.

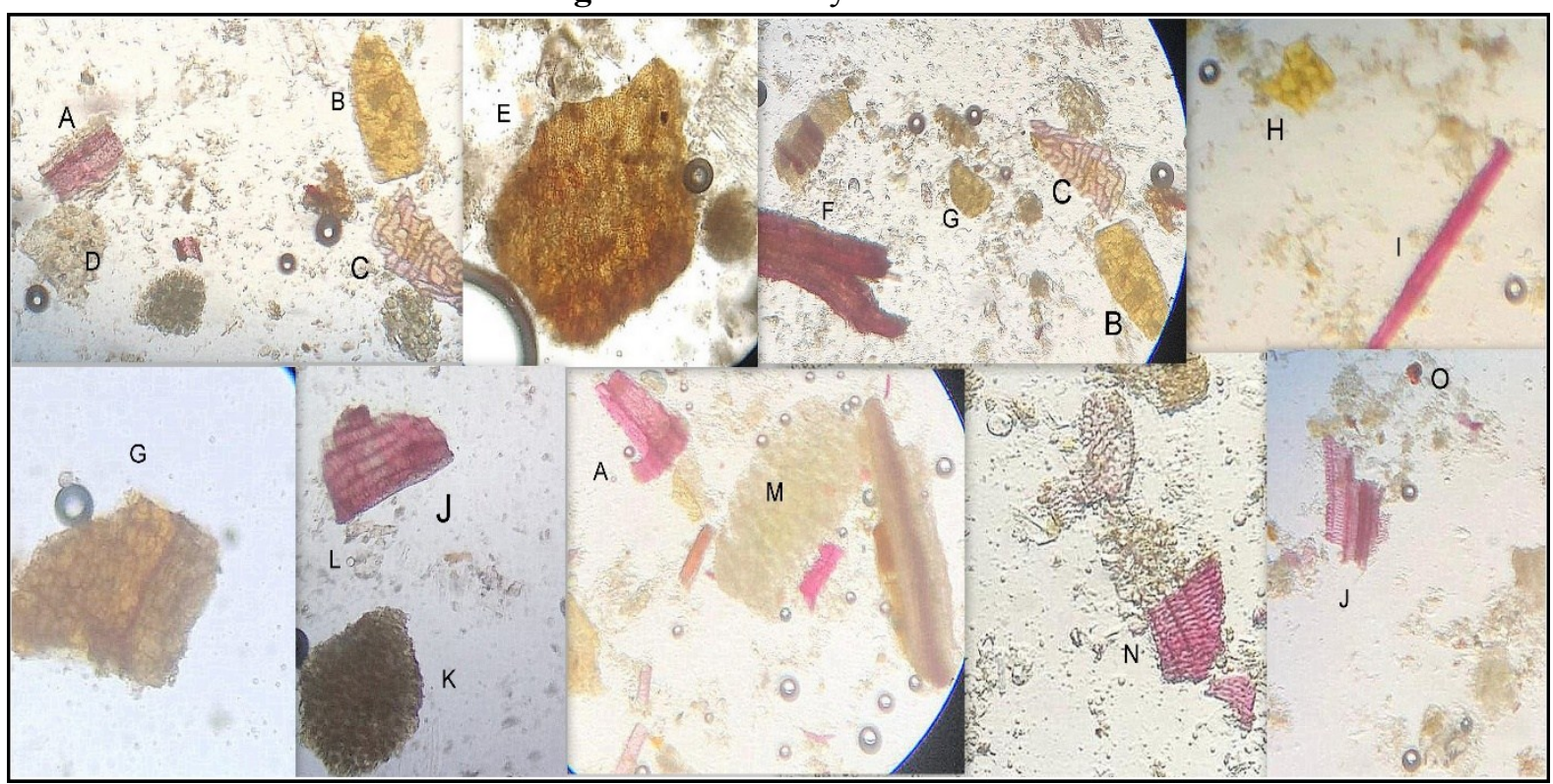

A: Lignified parenchyma of Shatavari Root B: Vittae of Ajmo C: mesocarp of carrot seed

D: Endosperm of Ajmo E: Cork of Liquorice Root F: Xylem fragments of Liquorice Root

G: Endocarp of Ajmo H: Cork of Ginger I: phloem fibre of liquorice root
J: Annular vessel of Shatavari root K: mesocarp of piper fruit L: starch grains of ginger

M: endosperm of Ajmo N: Scalariform xylem vessel of Shatavari Root

\section{Finished Products}

Table 2: Scale up formulation of cookies with base material

\begin{tabular}{|l|}
\hline S \\
\hline 1 \\
\hline 2 \\
3 \\
\hline 4 \\
\hline 5 \\
6 \\
\hline 7
\end{tabular}

\section{Ingredients}

Refined wheat flour

Ayurvedic herbs blend

Hydrogenated fat

Sugar

Skim Milk Powder

Baking Powder

Vanilla flavour (optional)
100 kg Batch Size Quantity $43 \mathrm{~kg}$

$7 \mathrm{~kg}$

$25 \mathrm{~kg}$

$25 \mathrm{~kg}$

$5 \mathrm{~kg}$

$0.4 \mathrm{~kg}$

$100 \mathrm{ml}$

Table 3: Scale up formulation soup with base material

\begin{tabular}{|l|l|l|l|}
\hline $\mathbf{S N}$ & Ingredients & $\mathbf{1}^{\text {st }}$ batch size $\left.\mathbf{( 5 0} \mathbf{~ K g}\right)$ & $\mathbf{2}^{\text {nd }}$ batch size $\left.\mathbf{( 6 0} \mathbf{~ K g}\right)$ \\
\hline 1 & Tomato powder & 22.5 & 27 \\
\hline 2 & Ayurvedic herbal mixture & 3.750 & 4.5 \\
\hline 3 & Corn starch & 7.500 & 9 \\
\hline 4 & Sugar & 10 & 12 \\
\hline 5 & Coriander & 1.5 & 1.8 \\
\hline 6 & Dehydrated Onion powder & 1.5 & 1.8 \\
\hline 7 & Dehydrated Garlic powder & 1.5 & 1.8 \\
\hline 8 & White pepper & 0.600 & 0.720 \\
\hline 9 & Salt & 3 & 3.6 \\
\hline Total & & 51.85 & 62.22 \\
\hline
\end{tabular}


Fig 2 Herbal soup and cookies Lab scale

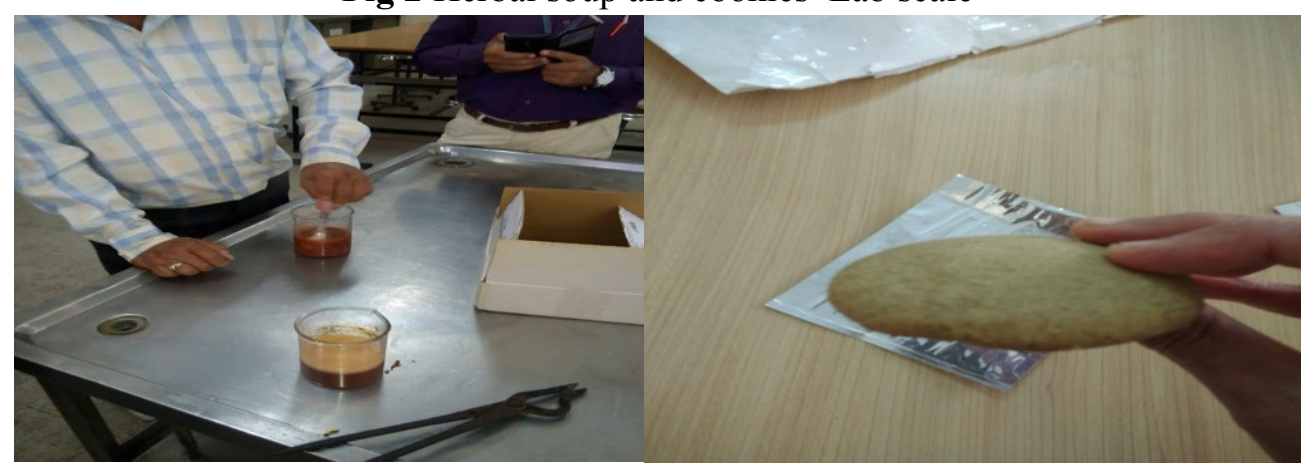

Fig 3 Herbal soup and cookies final with packaging

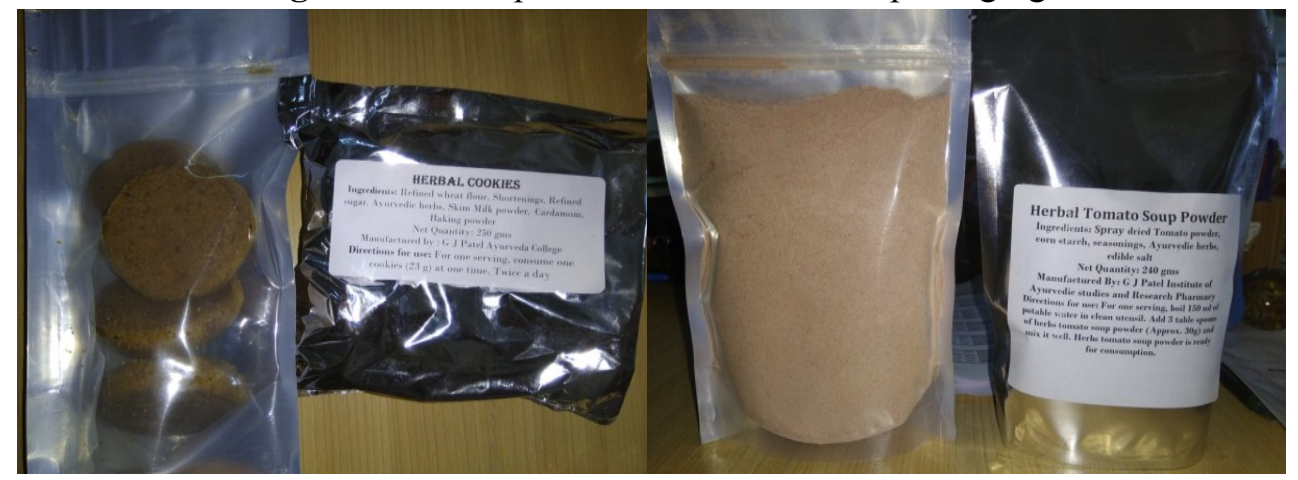

Table 4: Proximate composition of scale up products

\begin{tabular}{|l|l|l|l|}
\hline SN & Parameters & Tomato soup powder & Cookies \\
\hline 1. & Moisture content, \% & $9.15 \pm 0.69$ & $5.1 \pm 0.2$ \\
\hline 2. & Ash, \% & $14.4 \pm 1.2$ & $3.2 \pm 0.3$ \\
\hline 3. & Protein $(\% \mathrm{~N} \times$ x 6.25), \% & $4.7 \pm 0.6$ & $6.7 \pm 0.6$ \\
\hline 4. & Fat, \% & $0.8 \pm 0.2$ & $30.4 \pm 1.4$ \\
\hline 5. & Carbohydrate*, \% & 70.95 & 54.6 \\
\hline
\end{tabular}

*Carbohydrate content is estimated by difference method

\section{Heavy Metal Analysis of scale up products}

Five heavy metals (Zinc, Lead, Cadmium, Arsenic and Mercury) were quantitatively analysed in both samples. Results are depicted in Table 7.

Table 5: Heavy Metal analysis of scale up products

\begin{tabular}{|l|l|l|l|}
\hline Heavy Metal & $\begin{array}{l}\text { Instrument Detection } \\
\text { limit }\end{array}$ & $\begin{array}{l}\text { Ayurvedic herbs incorporated } \\
\text { cookies }(\mathrm{mg} / \mathrm{kg})\end{array}$ & $\begin{array}{l}\text { Ayurvedic herbs incorporated tomato soup } \\
\text { powder }(\mathrm{mg} / \mathrm{kg})\end{array}$ \\
\hline Zinc, $\mathrm{mg} / \mathrm{L}$ & $0.0059 \mathrm{mg} / \mathrm{L}$ & 9.4785 & 7.8588 \\
\hline Lead, $\mathrm{mg} / \mathrm{L}$ & $0.0420 \mathrm{mg} / \mathrm{L}$ & Not Detected & Not Detected \\
\hline Cadmium, $\mathrm{mg} / \mathrm{L}$ & $0.0027 \mathrm{mg} / \mathrm{L}$ & 0.0139 & 0.0200 \\
\hline Arsenic, $\mathrm{mg} / \mathrm{L}$ & $0.0530 \mathrm{mg} / \mathrm{L}$ & Not Detected & Not Detected \\
\hline Mercury, $\mathrm{mg} / \mathrm{L}$ & $0.0610 \mathrm{mg} / \mathrm{L}$ & Not Detected & Not Detected \\
\hline
\end{tabular}




\section{Clinical study observations}

Table 6: Number of participants registered

\begin{tabular}{|l|l|l|l|l|}
\hline & Group C (Cookies) & Group S (Soup) & Group R (Rajapravartini) & Total \\
\hline Registered & 50 & 50 & 50 & 150 \\
\hline Completed & 38 & 45 & 35 & 118 \\
\hline Dropped out & 2 & 2 & 0 & 4 \\
\hline LAMA (Left against medical advice) & 10 & 3 & 15 & 28 \\
\hline
\end{tabular}

Table 7: General information

\begin{tabular}{|l|l|l|l|l|l|}
\hline Age in years & $\begin{array}{l}\text { Group C } \\
\text { (Cookies) }\end{array}$ & $\begin{array}{l}\text { Group S } \\
\text { (Soup) }\end{array}$ & $\begin{array}{l}\text { Group R } \\
\text { (Rajapravartini) }\end{array}$ & Total & $\%$ \\
\hline $13-19$ & 10 & 13 & 14 & 37 & 24.66 \\
\hline $20-25$ & 40 & 37 & 36 & 113 & 75.34 \\
\hline $\begin{array}{l}\text { Haemoglobin }<12 \\
\text { gm \% }\end{array}$ & 13 & 17 & 18 & 48 & $32 \%$ \\
\hline
\end{tabular}

Table 8: Onset of pain

\begin{tabular}{|l|l|l|l|l|l|}
\hline Onset of pain & Group C (Cookies) & Group S (Soup) & $\begin{array}{l}\text { Group R (Rajapravarti- } \\
n i)\end{array}$ & Total & $\%$ \\
\hline Before menstruation & 15 & 18 & 17 & 50 & 33.33 \\
\hline First day & 41 & 43 & 44 & 128 & 85.33 \\
\hline $1-2^{\text {nd }}$ day & 0 & 0 & 3 & 3 & 2 \\
\hline
\end{tabular}

Table 9: Site of pain in dysmenorrhea

\begin{tabular}{|l|l|l|l|l|l|}
\hline Site of pain & Group C (Cookies) & Group S (Soup) & Group R (Rajapravartini) & Total & $\%$ \\
\hline Low back & 33 & 31 & 31 & 95 & 63.33 \\
\hline Hypogastrium & 33 & 29 & 32 & 94 & 62.66 \\
\hline Thigh & 21 & 20 & 21 & 62 & 41.33 \\
\hline Legs & 28 & 23 & 22 & 73 & 48.66 \\
\hline Calf & 3 & 1 & 3 & 7 & 4.66 \\
\hline Breast Tenderness & 1 & 1 & 1 & 3 & 2 \\
\hline Vulva & 1 & 1 & 6 & 8 & 5.33 \\
\hline
\end{tabular}

53 (38.13\%) girls remained absent during menstruation due to severe pain, whereas 24 girls $(17.27 \%)$ took medications and other treatment to relieve pain. 29 girls (20.87\%) girls suffered from pain during menstruation but continued their routine work, whereas in 33 girls $(23.75 \%)$ menstruation was not painful.
$127(84.67 \%)$ girls complained of scanty menstruation, 95 girls suffered from abdominal pain $(66.33 \%)$, 84 girls (56\%) had irregularity in menstruation, 71 $(47.33 \%)$ girls suffered from fatigue during menstruation, $55(36.66 \%)$ girls also complained of anorexia at the time of menstruation. 


\section{Clinical Study Results}

Chart 1: Comparative result in severity of pain Chart 2: Comparative relief in duration of pain

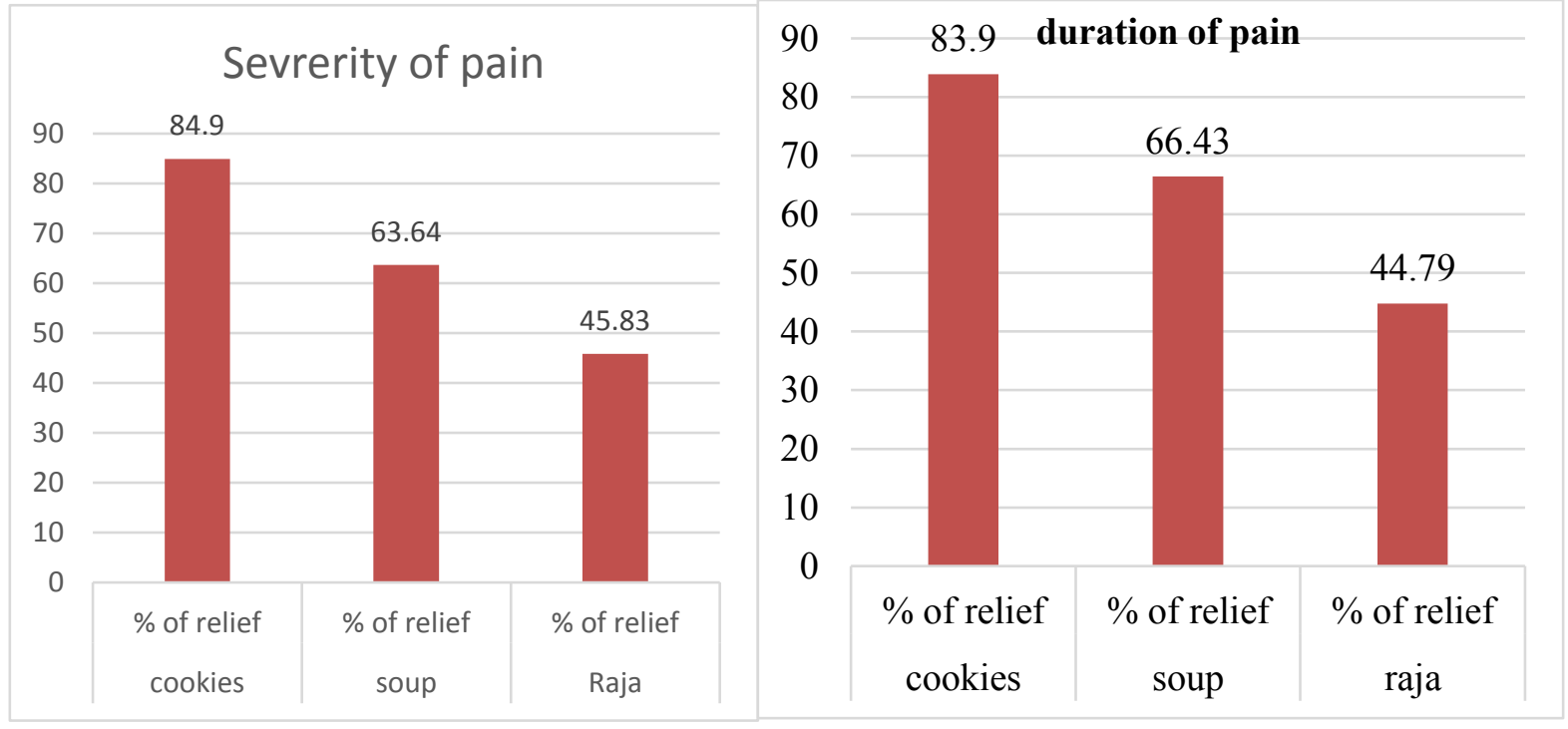

Chart 3: Comparative relief in associated symptoms

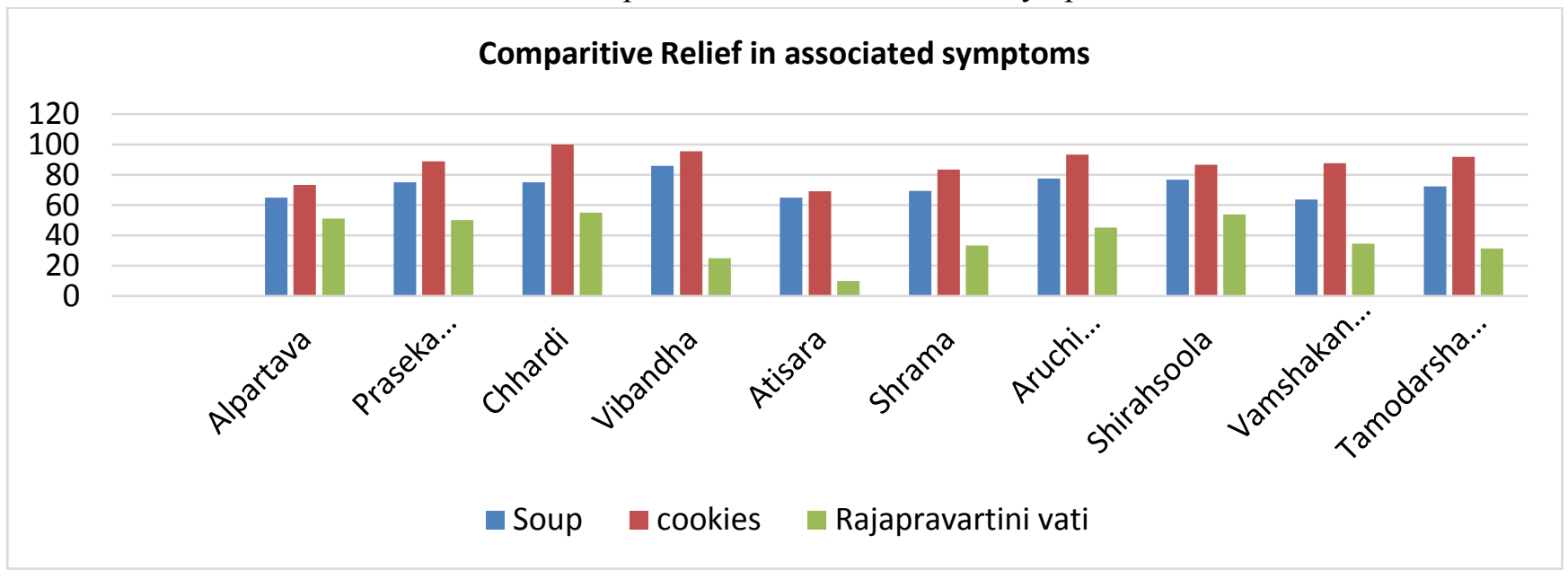

Chart 4: Total effect of therapy

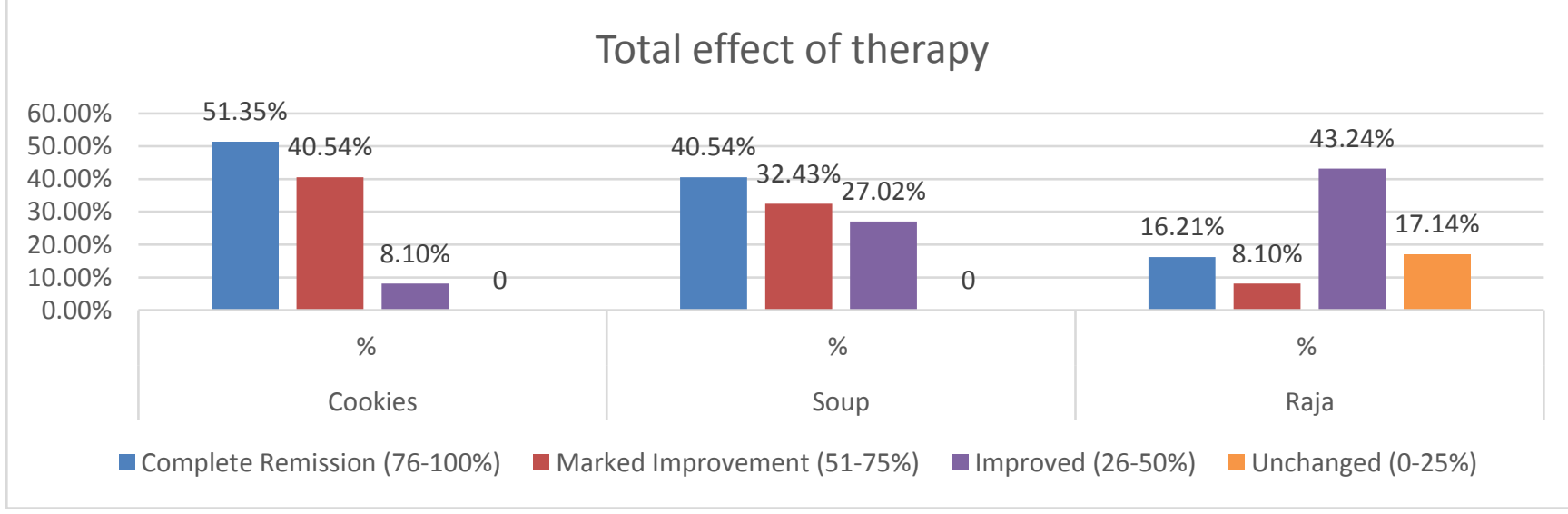


Statistical evaluation of three groups on haematological parameters showed no significant change in soup and cookies group in haemoglobin values. Whereas in Rajapravartini group statistically significant $(\mathrm{P}=0.005)$ improvement was seen in haemoglobin levels. This is because of content ferrous sulphate in the preparation which is haematinic. Statistically significant improvement was also found in Mean corpuscular haemoglobin and mean corpuscular haemoglobin concentration in cookies and soup group. This is because of haemopoetic factors present in herbal mixture as content in soup and cookies. The improvement in serum calcium levels was statistically significant in cookies group. Whereas, in soup and Rajapravartini Vati, the change was not significant.

\section{DISCUSSION}

To improve palatability of Ayurveda preparations and to design nutritional and restorative formulation, herbal cookies and herbal soup with common 12 Ayurveda ingredients were formulated, and clinical trial was done on Young girls with dysmenorrhea.

The cookies and soup group were readily acceptable by girls rather than Rajapravartni Vati. Total 15 girls out of 50 in Rajapravartini group left the treatment without information. They were reluctant to take tablets. In cookies and soup number of LAMA were 10 and 3 respectively. The new formulations also provided nutritional supplement and improvement in regularity of cycles. The mode of action of twelve herbs used as ingredients of new formulations is as under.

Table 10: Mode of action

\begin{tabular}{|c|c|c|}
\hline Sr No & Name & Mode of action \\
\hline 1 & Sunthi & $\begin{array}{l}\text { Produces analgesic effect by } \mathrm{COX}-1 \text { inhibition. }{ }^{5} \text {. Its supplementation not only increases absorption } \\
\text { of iron but also increases serum ferritin, total iron binding capacity which in turn corrects anaemia. } \\
\text { It is also rich in protein and has anti-inflammatory activity. }{ }^{6}\end{array}$ \\
\hline 2 & Jeeraka & $\begin{array}{l}\text { It regulates menstrual function through hormonal balance as it has anti estrogenic proper- } \\
\text { ties, }{ }^{7} \text { maintains calcium levels in body and hence has anti osteoporotic effect. }{ }^{8} \text { excellent source of } \\
\text { minerals like iron, copper, calcium, potassium, manganese, selenium, zinc and magnesium. It also } \\
\text { contains very good amounts of B-complex vitamins such as thiamin, vitamin B-6, niacin, ribofla- } \\
\text { vin, and other vital antioxidant vitamins like vitamin E, vitamin A and vitamin C. }{ }^{9} \\
\text { It also shows anti spasmodic activity and hence used therapeutically for spasmodic pain as in dys- } \\
\text { menorrhoea. }{ }^{10}\end{array}$ \\
\hline 3 & $\begin{array}{l}\text { Krishna } \\
\text { Jeeraka }\end{array}$ & $\begin{array}{l}\text { Effective in relieving pain and inflammation through its antispasmodic property. }{ }^{11} \text { Caraway seeds } \\
\text { are enriched with many important nutrients like vitamin A, B-complex, C and E. Mineral contents } \\
\text { such as calcium, magnesium, copper, iron, zinc, potassium, selenium and manganese }{ }^{12}\end{array}$ \\
\hline 4 & Pippali & $\begin{array}{l}\text { It has anti spasmodic action as well increases bioavailability and absorption of other herbs. }{ }^{13,14} \mathrm{It} \\
\text { also has immunomodulatory, antioxidant and adaptogenic effect, improves digestion. }{ }^{15}\end{array}$ \\
\hline 5 & Ajmoda & $\begin{array}{l}\text { It is used as an regulatory agent for women with irregular menstrual cycle by balancing estrogen } \\
\text { and producing estrous effect in ovarian cycle. }{ }^{16} \text { Anti spasmodic effects of its extracts due to block- } \\
\text { ade of voltage dependent calcium channels. }{ }^{17} \\
\text { Mineral elements such as calcium, potassium, magnesium, phosphorous, sodium, vitamin A, and } \\
\text { niacin. }{ }^{18}\end{array}$ \\
\hline 6 & Dhanyaka & $\begin{array}{l}\text { Antispasmodic activity }{ }^{19} \text { and induces estrous cycles for menstruation. }{ }^{20} \text { also induces regular men- } \\
\text { strual cycles. Also possess antioxidant activity. }{ }^{21} \text { It possesses analgesic activity. }{ }^{22}\end{array}$ \\
\hline 7 & Hingu & $\begin{array}{l}\text { It reduces contractile activity and hence causes antispasmodic effect due to its partial inhibitory } \\
\text { effect on histamine }(\mathrm{H} 1) \text { and potent inhibitory effect on muscarinic receptor. }{ }^{23,24} \text { In other study it } \\
\text { also showed relaxatory effect on pre contracted tissue. }{ }^{25}\end{array}$ \\
\hline 8 & Gajar Beeja & $\begin{array}{l}\text { It is antioxidant }{ }^{26} \text { and possess nutritional value because of present of molybdenum helping in ab- } \\
\text { sorption of iron. Also is good source of magnesium, which is helpful for bone, protein, relaxing } \\
\text { nerves and muscles }{ }^{27} \text { The seeds have especially shown antifertility - abortifacient effect by induc- } \\
\text { ing menstruation. }{ }^{28}\end{array}$ \\
\hline 9 & $\begin{array}{l}\text { Moolaka } \\
\text { Beeja }\end{array}$ & $\begin{array}{l}\text { Specifically shows antibacterial and antifungal activity invitro. It also shows antispasmodic activi- } \\
\text { ty. }{ }^{29}\end{array}$ \\
\hline
\end{tabular}




\begin{tabular}{|c|c|c|}
\hline 10 & Kumari & $\begin{array}{l}\text { It contains vitamin A B C E, Calcium, amino acids and enzymes. }{ }^{30} \text { In vitro study data shows that it } \\
\text { directly acts on enzymes } 3 \beta \text { HSD modulating the flux towards estradiol formation. Hence for regu- } \\
\text { larization of menstruation in cases with polycystis ovarian syndrome. }{ }^{31}\end{array}$ \\
\hline 11 & Shatavari & $\begin{array}{l}\text { Known female rejuvenative, adaptogenic. Regularizes menstrual function because of presence of } \\
\text { steroidal saponins Shatavarin I - IV which acts as phytoestrogen. It also contains vitamins A, B1, } \\
\text { B2, C, E. It is source of magnesium, Calcium and Iron. }{ }^{32,33} \text { It shows estrogenic effect. }{ }^{34} \text { One clini- } \\
\text { cal data also shows effect of Shatavari in minimizing risk of postmenopausal osteoporosis. }{ }^{35}\end{array}$ \\
\hline 12 & Yashtimadhu & $\begin{array}{l}\text { Contains isoflavones, a type of phytoestrogen for regularizing menstrual function. It decreases se- } \\
\text { rum testosterone on women and helps in reducing anaemia. }{ }_{36,37}\end{array}$ \\
\hline
\end{tabular}
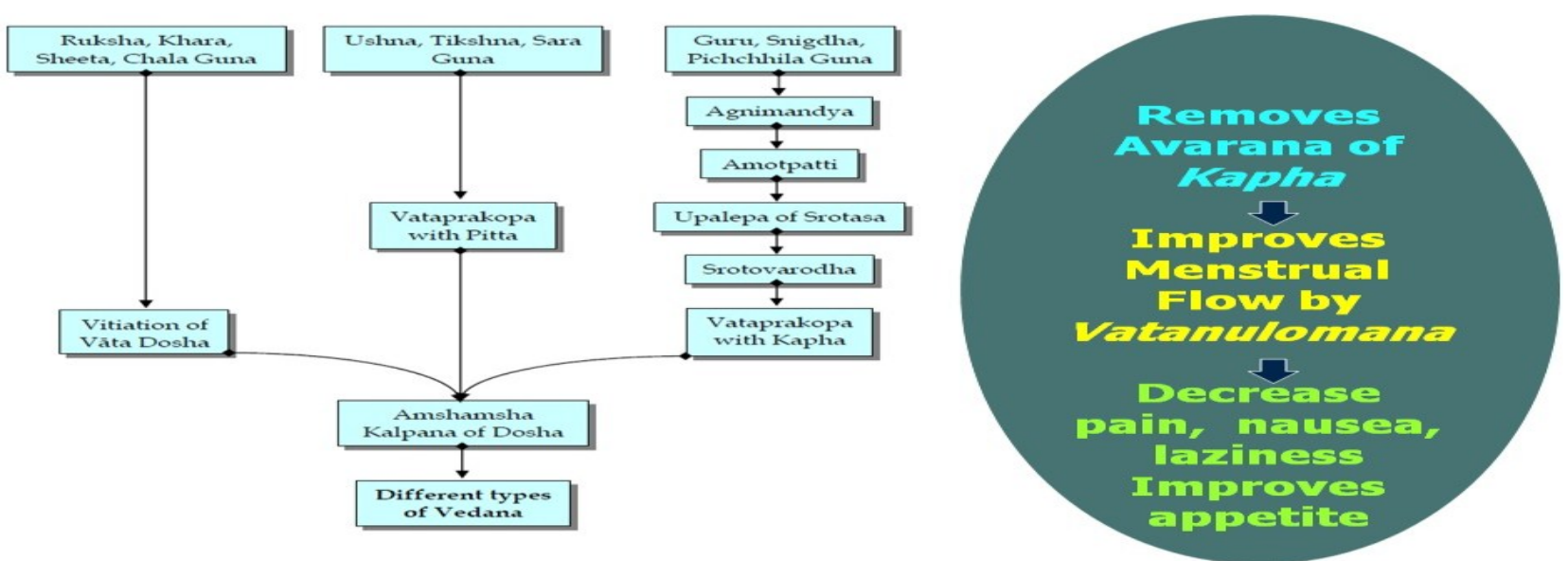

Fig 5: Pathology and mode of Action through Ayurveda concepts

\section{CONCLUSION}

Irregularity of menstrual cycle with abnormal BMI was observed with other associated symptoms of dysmenorrhea like scanty bleeding, fatigue, anorexia and others. Soup and cookies were palatable amongst girls and they were happy to take as a nutritional supplement also. Further studies can be done with large number of sample size as this was a pilot study of newly designed products.

\section{Acknowledgement}

The authors are extremely thankful to GUJCOST for awarding the minor research project. The authors also acknowledge with thanks to management of CVM, Principal GJP-IASR, ADIT and Director ARIBAS, Principal IICP for their constant support and help. We are grateful to Dr Marian, Ex Assistant Professor at IICP for her contribution for pharmacognosy evaluation.

\section{REFERENCES}

1. Kural et al. Menstrual characteristics and prevalence of dysmenorrhoea in college going girls. J Family Med Prim Care 2015 Jul-sept; 4(3) 426-431

2. Patel V, Tanksale V, Sahasrabhojanee M, Gupte S, Nevrekar P. The burden and determinants of dysmenorrhea: A population-based survey of 2262 women in Goa, India. BJOG. 2006; 113:453-63. [PubMed] [Google Scholar\}

3. Gujarathi Jasmine, Jani Dilip, Murthy ARV. Prevalence of menstrual disorders in hostellers and its effect on education - a cross sectional study. World Journal of Pharmaceutical Research. Vol 3 (2): Feb 2014: 40604065.

4. Premavati Tiwari, Ayurvediya Prasutitantra Evam Striroga, $2^{\text {nd }}$ Volume-Striroga, Chapter $2^{\text {nd }}$ Artavavyapada, Chaukhambha Orientalia, Varanasi, 2ndedition 2000 p139.

5. Nurtjahja-Tjendraputra E, Ammit A J, Roufogalis BD, Tran VH, Duke CC, Effective anti-platelet and COX-1 enzyme inhibitors from pungent constituents of ginger. Thromb Res, 111: 259-265, (2003

6. Subodh K, Singh UN, Kiran S, Ravi S. Supplementation of ginger with anti-tuberculosis treatment (ATT): 
A better approach to treat anemic pulmonary tuberculosis patients. International Journal of Herbal Medicine 2013; 1(3):17-20

7. Raj A, Singh A, Sharma A, Singh N, Kumar P, Bhatia V. Antifertility Activity of Medicinal Plants on Reproductive system of Female Rat. 2011; 2: 1-7

8. Shirke SS, Jadhav SR, Jagtap AG. Methanolic extract of Cuminum cyminum inhibits ovariectomy-induced bone loss in rats. Exp Biol Med. 2008; 233:1403-10

9. Parashar M, Jakhar M L, Malik CP. A Review on Biotechnology, Genetic Diversity In Cumin (Cuminum Cyminum) International Journal of life science and pharma research. Vol 4/ Issue 4/Oct-Dec 2014: 17-34

10. Modaress NV, Asadipour M. Comparison of the effectiveness of fennel and mefanemic acid on pain intensity in dysmenorrhoea. East Mediterr Health J 2006, 12: 423-27

11. Keshavarz A, Minaiyan M, Ghannadi A, Mahzouni P. Effects of Carum carvi L. (Caraway) extract and essential oil on TNBS-induced colitis in rats. Res Pharm Sci. $2013 ; 8(1): 1-8.45$.

12. https://www.nutrition-and-you.com/caraway-seed.html

13. Kumar S, Singhal V, Roshan R, Sharma A, Rembhotkar GW, Ghosh B. Piperine inhibits TNF- $\alpha$ induced adhesion of neutrophils to endothelial monolayer through suppression of NF- $\kappa$ and I $\kappa B$

14. Asian Journal of Biomedical and Pharmaceutical Sciences, all rights reserved. Volume 4, Issue 36, 2014. Bioavailability Enhancement by Piperine: A Review Shailendra Wadhwa*,1, Sarita Singhal2, Swati Rawat3

15. Agarhari Pooja, Singh DK. A Review of pharmacological aspects of Carum carvi. Journal of Biology Earth and Sciences; $2014: 4(1): 1-13$

16. Monsefi M, Ghasemi M, Bahaoddini A. Phytother Res 2006; 20(10): 865-8.

17. Gharib Naseri MK and Heidari A. Int J Pharmacol 2007; 3: 260-264.

18. Indo Global Journal of Pharmaceutical Sciences, 2012; 2(1): 36-42 Review on the Pharmacognostical \& Pharmacological Characterization of Apium Graveolens Linn Syed Sufiyan Fazal, Rajeev K Singla Sadbhavna College of Management \& Technology, Jalaldiwal, Raikot (Ludhiana), Punjab, India

19. Vedjani R et al. the efficacy of herbal medicine, Carmint on relief of abdominal pain and bloating in patients with irritable bowel syndrome; a pilot study, Dig Dis Sci 2006; 51(8): 1501-1507
20. Al Said MS et al. Post coital antifertility activity of seeds oc Coriandrum sativum in rats. J Ethnopharmacol 1987: 21 (2): 165-73

21. Agency for health research and development. Inventory Indonesian medicinal plants Vol II. Jakarta: Ministry of Health of Indonesia: 2001. Soeharso. Coriandrum sativum L. Vol 63. Jakarta: ASRI. 1988 p. 68

22. Bhat Sangeeta, Rizvi Waseem, Kumar Anil: Dose dependent effect of coriandrum sativum Linn seeds on thermal pain stimulus. The journal of phytopharmacology 2014: 3(4) 254-258

23. Mohommad F, Freshteh F, Hassanabad Z.F. J Ethnopharmacol 2004; 91:321-324

24. Gholamnezhad Z, Byrami G, Boskabady MH, Iranshahi M. Avicenna Journal of Phytomedicine 2012: 2: $10-16$

25. Fatehi $\mathrm{M}$ et al. Antispasmodic and hypotensive effects of Ferula asafoedita gum extract. Journal of Ethnopharmacology 91,2004: 321-324.

26. Sun $\mathrm{T}$ et al. Antioxidant Phytochemicals and antioxidant capacity of Bio fortified caroots (Daucus carota L.) of various colours. J. Agric. Food Chem. 2009; 57: 4142-4147.

27. Carlos Joao. Nutritional and health benefits of carrots and their seed extracts. Food and Nutrition sciences, 2014, 5, 2147-2156

28. Majumdar UK et al. Studies on Anti fertility of Methalonic Extract of Dacus carota Linn Seeds. Indian Journal of Natural Products. 1998: 14; 33-37

29. Aruna G et al. Phytochemicsty and Pharmacology of Raphanus sativus: International journal of drug formulation and research. Vol 3(1) 2012; 43-52

30. Joseph B, Raj SJ, Pharmacognostic and phytochemical properties of Aloe vera Linn an overview. International journal of pharmaceutical sciences review and research, 4(2), 2010, 106-110

31. Maharajan R et al. Effect of aloe barbadensis Mill. Formulation on Letrozole induced polycystic ovarian syndrome in rat model. J Ayurveda Integer Med 2010:1:273-9

32. Choudhary Deepika, Sharma Dimple. A phytopharmacological review on asparagus racemosus. International Journal of Science and Research. vol 3(7) 2014: 742746

33. Sharma Arti, Sharma Vandana. A brief review of medicinal properties of Asparagus racemosus. International Journal of Pure and Applied Bioscience. Vol 1(2); 2013: 48-52 
34. Tewari PV et al. Experimental study on estrogenic activity of certain indigenous drugs. J. Res. Ind. Med. Yoga and Homeo 1968: 11: 4-12

35. Japee Jasmine. A Comparative study on Shatavari and Kukkutanda Twak Basma in minimizing the risk of postemenopausal osteoporosis. AYU Vol 30(3): 2009: 314-317

36. Kaur et al. Glycyrrhiza glabra: A phytopharmacological review. IJPSR, 2011: vol 4 (7): 2470-77

37. Parvaiz $M$ et al. A review: Medicinal importance of Glycyrrhiza glabra L. Global Journal of Pharmacology Vol 8 (1): 2014: 8-13

\section{Source of Support: Nil \\ Conflict of Interest: None Declared}

How to cite this URL: Jasmine Gujarathi et al: Randomized Open Labelled Clinical Trial Of Herbal Cookies And Herbal Soup On Dysmenorrhoea - A Gujcost Sponsored Minor Research Project. International Ayurvedic Medical Journal \{online\} 2020 \{cited November, 2020\} Available from: http://www.iamj.in/posts/images/upload/2576_2586.pdf 